\title{
PENGARUH HARGA DIBUAT DENGAN "ANGKA KURANG" TERHADAP KEPUTUSAN MEMBELI
}

\author{
Nardi \\ Universitas Gadjah Mada
}

\begin{abstract}
INTISARI
Penelitian bertujuan untuk mengetahui pengaruh harga dibual dengan "angka kurang" (odd price) terhadap keputusan membeli. Adapun hipotesis yang diajukan adalah: ada pengaruh harga dibuat dengan "angka kurang" odd price terhadap keputusan membeli, of mana odd price mendorong subjek menetapkan pilihan barang dalam mengambil keputusan beli, dan subjek cenderung memurahkan terhadap produk-produk yang diberi label odd price. Penelitian dikiti oleh 40 subjek. Metode eksperimen mengambil disain Posttest only Control Group Design (disain kelompok pengendali hanya untuk puma uji). Pada kelompok kontrol sajian hanya terdiri atas even price, sedangkan di kelompok eksperimen terdiri atas old dan even price. Kelompok aksperimen dalam cara penyajiamya dibedakan secara serial dan pararel. Secara serial, di mana penyajian antara produk yang berlabel odd dan even price dilakukan pada ruang yang berbeda. Sedangkan parand adalah kedua label harga disajikan secara bersamaan dalam satu ruang. Sebelum eksperimen sesungguhnya, dilakukan pllot study sebagai persiapan dan penyempumaan terhadap segała sesuatunya yang berhubungan dengan alat eksperimen. Analisis statistik dilakukan dengan Chi-square. Hasil analisis statistik menunjukkan tidak ada pengaruh yang signifikan pada pemberian label odd pricing terhadap keputusan membeli produk-produk yang disajikan pada penelitian ini.
\end{abstract}

Kata kunci: Odd price even price, keputusan membeli, tahap pengambilan keputusan

Nardi, JahirBoyolali, Jawa Tengah, adalah alumnus Fakuttas Psikologi UGM. Saat in bekerja sebagai pengurus Yayasan Sakinah, Yogyakara, lembaga yang memiliki komitmen untuk mengembangkan ilmu-ilmu a'Qur'an. Memiliki pengalaman of bidang pemasaran.

\section{PENGANTAR}

$\mathbf{P}$ ada saat-saat tertentu pasar swalayan terlibat perang persaingan untuk menggaet konsumen. Tidak peduli apakah persaingan itu sehat atau tidak sehat, yang pasti perang persaingan antar pasar swalayan semakin ramai. Biasanya masingmasing pihak memiliki cara-cara atau kiat- 
kat tertentu, seperti potongan harga, memberi hadiah, dan sebagainya. Dalam hal harga, pasar swalayan tidak segan-segan membanting harga sampai $50 \%$ dari harga yang sebenarnya (Cempaka, 350/VII/13-19 Desember 1995).

Menetapkan harga atas produk yang hendak ditawarkan pada konsumen harus memperhatikan banyak faktor, bukan merupakan pertimbangan ekonomis semata. Meaurut Kotler (1988), harga mengkomunikasikan sesuatu mengenai produk yang bersangkutan.Sebagai contoh banyak konsumen menggunakan harga sebagai indikasi mutu. Sebuah botol parfum yang bernilai \$ 100 kemungkinan hanya berisi wewangian yang bernilai $\$ 3$, tetapi orang bersedia membayar $\$ 100$ karena hal ini menunjukkan sesuatu yang spesial.

Selanjutnya Kotler menambahkan bahwa faktor psikologis tidak bisa diabaikan dalam proses keputusan membeli. Perbedaan yang kecil dalam harga, dapat mengkomunikasikan perbedaan produk pada konsumen. Dicontohkan, sebuah stereo berharga $\$ 300$, sedangkan amplifier lainnya yang sama berharga \$299. 95. Perbedaan harga sebenarnya hanya 5 sen, tetapi perbedaan psikologisnya bisa sangat jauh lebih besar. Konsumen akan memandang $\$ 299$. 96 sebagai harga dalam rentang $\$ 200$ dan bukan dalam rentang \$ 300 (Harga \$ 200 sekian, dan bukan \$ 300 sekian).

Berdasarkan pada uraian singkat di atas, penulis ingin mengetahui apakah ada pengaruh harga dibual dengan angka kurang atau ganjil (odd price) terhadap keputusan membeli.

Informasi yang diperoleh dari penelitian ini, diharapkan dapat memberi sumbangan pada bidang psikologi pemasaran, khususnya di segi perilaku konsumen dalam melakukan proses pembelian. Secara praktis, diharapkan hasil penelitian ini akan menjadi salah satu acuan bagi praktisi rekayasa har- ga untuk kategori consumer goods. Di sisi lain, bagi konsumen diharapkan tumbuh kesadaran akan adanya "trik" tertentu dari fenomena odd price.

\section{TINJAUAN PUSTAKA}

Kotler (1988) membagi proses pengambilan keputusan membeli menjadi lima tahap; yaitu pengenalan masalah, pencarian informasi, penitaian alternatif, keputusan membeli, dan perilaku paska beli.

Menurut Engel (1975), kelima tahap tersebul tidak selalu terjadi. khususnya dalam pembelian yang kurang memerlukan keterlibatan pembeli. Konsumen bisa melompati tahap atau urutannya, tidak selalu harus sesuai dengan urutan d atas. Seorang wanita misalnya, yang berniat membeli pasta gigi yang sudah biasa dipergunakannya, akan mulai tahap langsung dari munculnya kebutuhan beli (tahap pengenalan) hingga keputusan membeli pasta gigi. Sedangkan tahap pencarian informasi dan evaluasi alternatif dilompatinya.

Pembuatan keputusan oleh konsumen. menurut Mowen (1990), diartikan sebagai penentuan pilihan terhadap dua atau lebih perolehan altematif dan proses penempatan sesudah atau sebelum menentukan pilihan. Proses keputusan membeli oleh konsumen berhubungan langsung dengan bantuan pemasaran (marketing $m i x$ ), segmentasi, dan riset pemasaran. Khususnya tentang harga. di mana pada kondisi harga merupakan atribut dominan dari suatu produk yang tersajt. pengetahuan tentang strategi harga dirasakan sangat penting.

Harga ganjil (odd price) adalah salah salu teknik penetapan harga dengan memakai pertimbangan psikologis. Odd price sendiri mempunyai dua pengertian, yaitu: harga yang berakhir dengan angka ganjil (odd number) atau harga yang berada sedikit di bawah harga bulat penuh, kurang sedikit de- 
ngan even price-nya (Monroe, 1992; Clemente, 1993).

Pada umumnya para retaiter percaya bahwa harga-harga dengan angka ganjil (ood number) akan memberikan efek penjualan lebih banyak, karena angka tersebut meng. ilustrasikan sebagai harga yang lebih murah. Suatu produk lebih mudah dijual dengan harga Ap. 695 (odd price) daripada Rp. 700 (even price). Hal ini didasarkan pad a pertimbangan bahwa pembeli akan berpikir bahwa harga tersebut berada dalam rentang Rp. 600,00-an dan bukan Rp. 700,00-an. Meski perbedaan nominal hanya Rp. 5,00 akan tetapi perbedaan harga psikologisnya dapat jauh lebih besar. Hampir semua persepsi konsumen tentang odd price sebagai lebih murah daripada evenprice(Clemente, 1993; Lambert, 1975).

Persepsi bukanlah cermin dari realitas yang ada, melainkan sangat dipengaruhi oleh pengharapan, pengalaman, dan motivasi. Rakhmat (1993) mengatakan bahwa persepsi merupakan pengalaman terhadap objek, peristiwa atau hubungan yang diperoleh dengan menafsirkan dan menyimpulkan informasi.

Dilihat dari kacamata teori persepsi, fenomena odd price di atas di dalam aliran psikologi Gestalt, bisa didekati dengan prinsip proximity (keterdekatan). Kaidah proximity menjelaskan bahwa stimulus yang disajikan bersamaan cenderung untuk dikelompokkan dengan yang dianggap lebih di dalam medan persepsi kita. Atau dengan kata lain, objek-objek yang ditanggapi secara runtun berdekatan sebagai satu kesatuan (Hahn, 1976; Chaplin, 1995). Sehingga, misalnya, ketika di hadapan subjek disajikan angka 300 dengan 2, 99 bagi subjek yang bersangkutan angka 2, 99 tersebut dlpersepsi lebih dekat ke 200-an daripada ke 300 .

Scwartz dan Reisberg (1991) menengaral adanya anchoring effect dalam proses persepsi. Teori ini menjelaskan adanya kecenderungan subjek memilih stimulus yang paling awal atau tepi sebagai anchor (jang. kar) dari estimasi yang dibuatnya. Dapat dicontohkan, seandainya ada dua stimulus disejajarkan, misałkan angka 695 dengan 700 , maka angka enam dan tujuh tersebut berfungsi sebagai anchordari estimasi yang dibuat oleh subjek. Hal ini disebabkan seringkali estimasi yang dibuat oleh subjek dimulai dari huruf atau stimulus awal yang kemudian diadakan penyesuaian dengan cara dinaikkan atau diturunkan untuk memperoleh jawaban akhir.

Fenomena odd price ini secara psikologi bisa diterangkan dengan hukum primacy effect. Kaidah ini menerangkan bahwa informasi yang di muka memiliki pengaruh lebih kuat (significant) bagi seseorang dari pada yang berikutnya (Mowen, 1990; Ellis dan Hunt, 1993; Solomon dalam Rakhmat, 1993). Hal ini dikarenakan informasi perfama masuk ke shorttenn memory, dengan demikian memiliki kesempatan lebih (adequate) untuk diulang (rehearsal), dan yang berikut: nya ditransfer ke dalam ingatan jangka panjang (long-term memory).

Tentang primacy effect, A. Kahnem dkk. (dalam Batzin dkk, 1983) mengatakan bahwa suatu intormasi yang perfama kali masuk ke dalam pikiran memiliki pengaruh lebih kuat terhadap pengambilan keputusan (judgment) dari pada yang belakangan.

\section{METODE PENELITIAN}

Subjek dalam eksperimen ini adalah mahasiswa Fakultas Psikologi UGM angkatan 1996 sebanyak 40 orang. Disain yang djpakai adalah Posttest Oniy Control Group Design (disain kelompok pengendali hanya untuk purna uji), yang merupakan dua kelompok terakhir dari disain em pat kelompok Solomon (dalam Kinnear dan Taylor, 1987) disimbolkan dengan: 
Kelompok Eksperimen : $\mathrm{A} \times \mathbf{O}$. Kelompok Kontrol : $\mathrm{F} \quad \mathrm{O}_{2}$

Sebelum eksperimen yang sesungguhnya dilakukan, pilot study terlebih dahulu sebagai persiapan untuk eksperimen yang sesungguhnya. Alat yang dipakai untuk mengumpulkan data berupa daftar barang yang dibeli dan pilihan harga baik odd ataupun even prico dengan sebelumnya subjek dibagi atas dua, kelompok eksperimen dan kelompok kontrol. Barang-barang di kelompok eksperimen terdiri atas odd dan even price, sedangkan dalam kelompok kontrol hanya terdiri atas even price saja. Kelompok eksperimen sendiri dibedakan menjadi dua kelompok penyailian seçara serial dan pararel. Di dalam penyajian secara pararel, kedua harga disajikan secara bersamaan dalam satu ruang, sedangkan dalam cara serial disajikan secara berurutan di dua ruangan. Analisis statistik terhadap data yang telah terkumpul dilakukan dengan Chi-square.

Sebelum produk yang bersangkutan dipakai untuk eksperimen, diadakan kontrol terhadap variabel produk yang dianggapdapat berpengaruh terhadap hasil yang ingin dicapai dari penelitian ini, dengan cara diadakan pembungkusan ulang (r. - packaging). Adapun produk yang dieksperimenkan ada lima macam yaitu: sabun mandi, sikat gigi, pasta gigi, buku tulis dan ballpoint.

\section{HASIL PENELITIAN DAN ANALISIS DATA}

Hasil penelitian ini menunjukkan tidak ada pengaruh yang signifikan pada harga yang dibuat dengan "angka kurang" (odd price) terhadap keputusan membeli, dari semua produk yang dipakai untuk eksperimen, disajikan pada Tabel 1 :

Tabel 1

Frekuensi Subjek Menuru! Keputusan Membeli

\begin{tabular}{|c|c|c|c|c|c|c|c|}
\hline \multirow{2}{*}{ No. } & \multirow{2}{*}{$\begin{array}{c}\text { Nama } \\
\text { Produk }\end{array}$} & \multicolumn{2}{|c|}{$\begin{array}{c}\text { Kelompok Kontrol } \\
\text { (oven price) }\end{array}$} & \multicolumn{2}{|c|}{$\begin{array}{c}\text { Kelompok } \\
\text { Eksperimen } \\
\text { (even-odd price) }\end{array}$} & $\begin{array}{c}\text { Chi- } \\
\text { Square }\end{array}$ & $P$ \\
\cline { 2 - 6 } & Beli & Tidak Beli & Beli & Tldak Benl & \\
\hline & $\begin{array}{c}\text { Sabun } \\
\text { mandi }\end{array}$ & 16 & 4 & 16 & 4 & 0,0000 & $\begin{array}{c}1,000 \\
0\end{array}$ \\
\hline 2 & Sikat gigi & 14 & 6 & 14 & 6 & 0,0000 & $\begin{array}{c}1,000 \\
0\end{array}$ \\
\hline 3 & Pasta gigi & 13 & 7 & 17 & 3 & 1,2000 & $\begin{array}{c}0,273 \\
3\end{array}$ \\
\hline 4 & Buku tulis & 10 & 10 & 15 & 5 & 1,7066 & $\begin{array}{c}0,191 \\
4\end{array}$ \\
\hline 5 & Ballpoint & 12 & 8 & 17 & 3 & 2,0062 & 0,156 \\
6
\end{tabular}


Kemudian pembagian cara penyajian dengan setial-paratel diperlihatkan di Tabel 2 :

Tabel2

Pembagian Secara Serial-Paralel dan Pilihan Harga

\begin{tabular}{|c|c|c|c|c|}
\hline & Odd price & Even price & $X^{2}$ & $P$ \\
\hline serial & 16 & 27 & \multirow{2}{*}{1,30766} & 0,25282 \\
\hline paralel & 18 & 18 & & \\
\hline
\end{tabular}

Berdasarkan analisis data pada Tabed 1. ditemukan bahwa hasil uj antara penyajian harga dengan keputusan membeli tidak signifjkan dengan $p>0,05$. Dengan demikian tidak ada pengaruh harga dibuat dengan "angka kurang" (odd price) terhadap keputusan membeli. Sedangkan pembedaan cara penyajian pada kelompok eksperimen secara serial dan pararel berdasar analisis pada Tabel 2 tiofak signifikan, di mana $\mathrm{p}>0,05$. Hal ini berarti kondisi tersebut dianggap sederajat, sehingga tidak perlu diadakan analisis tersendiri terhadap kedua kondisi tersebut.

\section{PEMBAHASAN}

Sebelum diadakan penelitian sesungguhnya, terlebih dahulu diadakan pilot study sebagai upaya peneliti untuk menyempurnakan segala sesuatu yang berkattan dengan penelitian sesungguhnya. Prosedur yang harus dilakukan oleh subjek baik dalam pilot studyataupun dalam eksperimen yang sesungguhnya adalah tidak banyak mengalami perubahan. Pad a pilot study harga barang-barang yang dijual rata-rata di bawah Rip. $1.000,00$ sedangkan pada penelitian sesungguhnya diubah menjadi di atas Rip. $1.000,00$ baik untuk odd maupun even price. Adapun alur penelitian yang harus diikuti oleh subjek baik pada pilot study maupun eksperimen yang sesungguhnya sama, baik mulai dari instruksi sampai pengisian kuesioner.

Sebelum masuk ke pokok-pokok materi yang ingin disampaikan, ada baiknya kalau disajikan perbandingan secara sepintas antara suasana belanja yang biasanya ditemui pada pasar swalayan pada umumnya dengan suasana belanja pada waktu eksperimen diadakan. Tabel 3 memperlihatkan perbedaan secara umum antara kedua kondisi tersebut. 
Tabel 3

Perbandingan Suasana Belanja dalam Peneltian dengan Sesungguhnya

\begin{tabular}{|l|l|}
\hline \multicolumn{1}{|c|}{ A. Suasana sesungguhnya } & \multicolumn{1}{c|}{ B. Suasana penelitian } \\
\hline 1. Niat beli sejak dari rumah & a. Niat beli diciptakan belakangan \\
\hline 2. Produk "betul-betul" dibutuhkan & b. Produk belum tentu dibutuhkan \\
\hline 3. Uang dari penghasilan & c. Uang diberi di tempat penelitian \\
\hline 4. Variasi merek banyak & d. Tanpa merek \\
\hline 5. Warna kemasan variatif & e. Kemasan satu warna (tiada pilihan) \\
\hline 6. Setting-lay out ruang menarik & f. Selling-lay out ruang biasa saja \\
\hline 7. Seringkali ada musik pengiring & g. Tanpa musik \\
\hline
\end{tabular}

Melihat perbandingan sepintas di atas, tampak bahwa antara situasi buatan (artificial environment) dalam penelitian ini, dengan apa yang ada dalam keseharian banyak perbedaannye. Padahal di sisi lain disadari bahwa para subjek inipun dalam kesehariannya juga berbelanja peda situasi yang sesungguhnya sebagaimana tersebut: di atas.

Ditolaknya hipotesis dalam penelitian ini, bahwa ada pengaruhnya harga dibua: dengan "angka kurang" (terjemahan bebas dari odd price), adalah menarik untuk dikaji lebih mendalam. Ini berarti anggapan dari sebagian para retallerbahwa pencantuman odd pricing di hampir semua label harga barang yang dijual oleh pasar swalayan akhirakhir ini akan dapat menaikkan tingkat penjualan adalah layak untuk ditinjau ulang. Artinya sebagaimana hasil dari penelitian ini, bahwa pencantuman add pricedi hampir semua label harga produk seperti yang semakin meruyak dewasa ini belum menjamin akan menambah tingka: penjualan produk dibandingkan ketika produk yang sama tersebut diberi label harga even price.
Data tersebut walaupun sudah memakai perangkat analisis stafistik yang memadai, namun skuprya masih terbatas pada suasana laboratoris (artificial environment) di mana jumlah sampel produk yang diteliti sangat terbatas. Sementara itu dalam kenyataan yang sebenarnya perlu dicermati adanya faktor-faktor rill yang mungkin akan memberikan kompleksitas terhadap permasalahan yang tengah dikaji.

Ketika daya beli konsumen yang makin meningkat, sehingga berpengaruh terhadap persepsi nilai uang itu sendiri, maka akan mengakibatkan selisin nilai intrinsik mata uang antara even dengan odt prico menjad tidak berarti. Pada konsumen yang semakin rasional, odd price tersebut bisa disadari tidak lebih sebagai trik para pelaku bisnis, yang bermain-main secara psikologis pada kelemahan persepsual konsumen terhadap fenomena odd number (baca: primary offect).

Ada banyak faktor yang dalam kenyataannye berpengaruh terhadap perilaku beli konsumen. Tabel 3 di atas menunjukkan bahwa macam variesi stimulus yang melingkupi sebuah perilaku beli (buying behavion) 
yang berlangsung di ruang eksperimen dengan realitas of lapangan jauh berbeda. Berangkat dari asumsi, bahwa penyajian aneka rag am stimulus di pasar-pasar swalayan tersebut adalah untuk mendukung tingkat kenyamanan berbelanja bagi para konsumen, hadirnya fenomena odd pricingdalam kaitannya dengan keputusan beli yang diambil oleh individu dałam situasi eksperimen dengan realitas di masyarakat ditangkap relatif sama. Namun demikian, data penefitian d afas menunjukkan bahwa murahnya odd pricingtidak berkorelasi positif dengan keputusan pemilihan harga oleh subjek. Oleh karena itu, dimungkinkan adanya faktor-faktor lain yang berpengaruh terhadap perilaku konsumen.

Labeling harga bukanlah satu-satunya faktor dominan dalam perilaku bel: Menurut Mowen (1990), suasana ruang dan fisik (physical surrounding) yang ada di dalam lingkungan belanja berpengaruh kuat terhadap aktivitas konsumen. Selanjutnya dikatakan Mowen bahwa stimulus-stimulus seperti: warna, suara, cahaya, iklim, dan penataan ruangan dapaf juga berpengaruh terhadap variasi perilaku belanja.

Sebagai contoh kecil dari apa yang dikatakan oleh Mowen of afas, dapat dilihat dari riset tentang pengaruh musik terhadap proses belanja yang pernah diadakan oleh Milliman (1992). Dalam penelitian ini disajikan dua macam jenis musik, kemudian dilihat bagaimana pengaruh musik yang disajikan sebagai pengiring suasana belanja terhadap para konsumen di suału supermarket. Penelitian berjalan selama periode sembilan minggu, yang pertama adalah diciptakan suasana belanja yang tanpa diiringi musik, kemudian periode berikutnya disajikan musik tempo lambat (slow-tempo music) dan akhirnya musik tempo cepat (faster-tempo music). Hasil dari penelitian ini menunjukkan pola berjalan dengan cepat atau pelan-pelan (perlahan) tergantung pada apakah musik yang disajikan tersebut jenis fast atau slow. Di sisi lain terdapat kenaikan tingkat penjualan sebesar $38 \%$ ketika jenis musik slow disajikan.

Bukan hanya faktor lingkungan fisik saja yang berpengaruh terhadap perilaku beli, tetapi faktor kemasan (packaging) produk pun tidak kalah besar konfribusinya dalam mempengaruhi perilaku belanja konsumen. Menurut Lincoln dan Gardner (dalam Hansen, 1972), kemasan mengkomunikasikan produk. Artinya bagaimana penampilan produk (pembungkusan) berpengaruh terhadap persepsi konsumen terhadap produk itu sendiri.

Nama merek (brand name) dari produk yang dijual kepada konsumen barangka!l memberikan diyakini sumbangan yang terbesar terhadap pengambilan keputusan beli konsumen. Larzellere dkk. (dalam Hansen, 1972) mengatakan bahwa konsumen akan mau membayar dengan harga lebih tinggi untuk merek-merek yang mempunyai nama yang sudah jelas. Hal ini didasarkan pada asumsi bahwa nama merek tertentu berarti mengidentifikasikan sebagai kualitas lebih tinggi.

Bagaimana hal ini bisa terjadi? Menurut Kertajaya (1996), brand name yang berangkat dari just a nameakan berubah menjadi brand awareness, kemudian dari sini akan menjadi suatu asosiasi merek bagi konsumen yang bersangkutan, dan selerusnyar. lebih kuat mencengkeram persepsi konsumen terhadap produk tersebut sebagai suaus produk yang berkualitas. Kalau sudah demikian, tentu saja muaranya berupa tingkat loyalitas yang tinggi terhadap merek tersebut. Akhirnya, tentu saja bisa disimpulkan akan adanya ketergantungan secara psikologis tersendiri bagi konsumen terhadap merek yang bersangkutan, di mana konsumen akan selalu melakukan pengulangan pembelian lebih dikarenakan dorongan yang kuat dari dalam diri konsumen (Day, dalam 
Dick \& Basu, 1994).

Penelitian yang senada dengan Larzellere pernah dilakukan oleh Vitriani (1995). Vitriani menemukan bahwa faktor merek masih merupakan pertimbangan utama dalam membuat keputusan membeli oleh sebagian konsumen. Asumsi dasar yang dipakai adalah merek berpengaruh terhadap persepsi tentang kualitas produk yang akan dibeli. Menurut Loudon dan Bitta (1984), pengambilan keputusan beli dipengaruhi oleh berbagai faktor. Merek merupakan salah satu faktor yang dipertimbangkan dalam pembelian produk. Dengan demikian keberadaan merek menjadi penting dalam kerangka menarik konsumen untuk membeli produk yang dimaksud.

Bukan hanya faktor physical surrounding, packaging, dan faktor merek saja yang berpengaruh terhadap buying behaviorkonsumen. Tertu saja faktor harga tetap merupakan sisi yang harus dicermati. Aaker (1991) mengatakan bahwa daiam pembelian barang, harga secara konsisten dan kuat dirasakan sebagal indikator kualitas oleh konsumen, nyaris sekuat nama merek. Keterkaitan harga sebagai indikator kualitas tergantung pada keberadaan indikator lain. Artinya, bila atribut intrinsik produk (spesifikași produk) tidak ada, maka harga dipakai sebagai indikator kualitas produk, kemudian faktor dalam diri konsumen, darn sejauh mana keterlibatan konsumen dengan produk tersebut.

Moore dar Hutchirson (1984) menguatkan pendapat Aaker di atas, bahwa hubungan antara harga dengan kualitasmerupakan hubungarn yarng berbanding lurus. Artinya, makin tirgggi harga berarti makin berkualitas, sebagaimana ungkaparn "You get what you pay t $^{\prime \prime}$ (ono rego ono rupo).

Menurut Monroe (dalam Furqony, 1996). ambang batas penerimaar harga (price threshold menjadikan konsumen menilai apakah dua buah barang yang berbeda har- ganya akan memiliki perbedaan penilaian. Artinya jika harga dipersepsi masih berada dalam spektrum yang sama, maka konsumen memandang tidak ada perbedaan yang dirnunculkan (signifikan) oleh perbedaan harga tersebut.

Tentang fenomena sensitivitas harga tersebut, Nagle (dalam Kotler \& Roberto, 1989) berkomentar bahwa mengukur sensitivitas harga adalah satu ha, sedangkan menatap kenapa hal itu bisa terjadi adalah hal lain. Selarjutrnya Nagle mengatakan ada banyak faktor yang ditengarai berpengaruh terhadap sensitivitas harga. Dua di antararya adalah apa yang disebut dengan kaidah unique-value effect di mana konsumen akan kehilangan sensitivitas harganya apabila produk yang dijual tersebut memiliki keurikan tertertu. Kemudian yang kedua adalah price-quality effect, yakni konsumen juga bisa saja kehilanngan sensitivitas harga apabila produk yang dijual diasumsikan sebagai produk yang memiliki kualitas, prestise, atau bersifat eksklusif.

Kemudian suasana lingkungan pergaulan (social surrounding) jug a ditengarai ikut mempengaruhi buying behavior. Pengaruh ini bisa datang dari kelompok pergaulan ataupun secara individual. Dorongan pergaulan (social motive) dapat juga dilihat sebagai penyebab dari keadaan, mengapa seseorang bepergian ke suatu tempat ataupun berbelarja. Mernu rut Tauber (dalam Mower, 1990), pengalaman berbelanja bagi seseorang seringkail dianggap sebagai sesuatu yang penting. Mengapa? Hal iri dikarenakan bagi orang tertentu berbelanja adalah arena atau ajarng bertemu dengan orang-orang yang baru, dan siapa tahu bisa dijadikan teman baru.

Dilihat dari kaca mata bisnis, tentu hal ini sebagai fenomena yang menarik, khususnya bagi seorang retaller untuk memperluas keuntungan yang bisa ditangguknya. Studi yang pernah diadakan oieh Granbois (dalam 
Mowen, 1990) menemukan bahwa ketika seseorang berbelanja bersama dengan orang lain, konsumen (he or she) cenderung mengunjungi lebih banyak rak (stores) daripada ketika belanja sendirian. Konsumen cenderung lebih banyak membuat keputusan beli yang tidak direncanakan sebelumnya, atau dengan kata lain yang sering terjadi adalah buying by impulse.

Ditemukan dalam penelitian ini bahwa subjek cenderung menganggap lebih murah terhadap produk-produk yang diberi label odd pricemenunjukkan berlakunya hukum primacy effect. Akan tetapi, hal ini tidak berkorelasi secara langsung dengan keputusan beli. Maksudnya subjek sadar bahwa barang-barang yang berlabel odd priceitu lebih mu rah dari pad a even price, dan hal ini belum cukup mempengaruhi subjek cenderung untuk memilih atau mengganti yang dibelinya dengan barang-barang yang berlabel odd price.

Riset yang pernah dilakukan Schindler dan Wiman (dalam Monroe, 1990) menyimpulkan bahwa konsumen merasa lebih sulit untuk mengingat oof price daripada even price, dan mempunyai kecenderungan meremehkan harga ganjil yang sebenamya.

Selanjutnya dikatakan oleh Schindler dan Wiman, bahwa kesulitan konsumen dalam mengingat odf price adalah sesuatu yang tidak jelas. Penilaian selanjutnya mengindikasikan bahwa oddpricemengkomunikasikan sebagai hal (baca: harga) yang lebih rendah (murah), dan kualitas rendah (a low quality image).

Inilah barangkali yang terjadi, ketika diadakan pilot stuofy, kelompok eksperimen dalam menjawab harga yang tertera pada label barang (dengan cara riscal) cenderung menjawab salah (ada yang menaikkan, ada yang menurunkan harga). Hal ini tidak terjadi pada kelompok kontrol yang menjawab dengan tepat sesuai yang tertera dalam label harga barang.
Apakah odd price itu sendiri betul-betul dapat meningkatkan penjualan atau tidak, dikarenakan bukan hanya faktor harga saja yang berpengaruh terhadap keputusan beli. menurut Clemente (1989), diserahkankepada masing-masing pelaku (retailer) dalam memperkirakannya. Namun dernikian, maraknya pemakaian odd price di hampir se mua pasar swalayan dewasa ini memberikan banyak kontribusi positif dalam bidang penjualan ini.

\section{PENUTUP}

Berpijak pada data di muka, maka dapat disimpulkan bahwa dalam penelitian ini tidak ditemukan bukti adanya pengaruh harga dari suatu produk (consumer goods) yang kita jual dengan diberi label harga antara dengan "angka kurang" atau harga ganjil (odd price) terhadap keputusan beli. Kemudian pada subjek yang memilih barang-barang dengan odd price terbukti cenderung memurahkan harga-harga tersebut. Hal ini berart hukum primacy effect berlaku. Dengan demikian, meskipun subjek sadar bahwa odd price lebih mu rah daripada even price, akan tetapi ini tidak cukup membuat subjek selalu menetapkan pilihannya pada barang-barang yang berlabel ood price.

Berpijak pada data hasil penelitian ini, bahwa pada situasi laboratoris di mana faktor-faktor di luar harga diupayakan dikontrol sedemikian rupa, maka peneliti menyarankan khususnya bagi para penelitian sejenis yang akan datang, untuk memperhatikan atau mengikutsertakan faktor-faktordi luar harga penelitian sejenis di masa mendatang. Hal ini layak untuk dicermati mengingat realitas di lapangan banyak sekaii faktor di luar harga yang berpengaruh terhadap perilaku beli.

Bagi produsen, berdasar pada hasil penelitian di atas, bahwa tidak ada bedanya antara pencantuman harga baik dengan odd 
price ataupun even price sebàgaimana hasi penelitian ini, maka layak untuk dicoba pencantuman harga dengan memakai even price, karena hal ini berarti akan meningkatkan margin keuntungan.

Bagi konsumen diharapkan lebih rasional di dalam perilaku belinya. Pada situasi di mana sedernikian banyak stimulus yang berpengaruh terhadap perilaku beli, sangat mungkin sekali hal ini akan mengurangi tingkał kekritisan konsumen dalam pengambilan keputusan belinya. ๖

\section{DAFTAR PUSTAKA}

Aaker, D.A. 1991. Managing Brand Equily. New York: The Free Press A Division of Macmillan Inc.

Chaplin, J.P. 1995. Kamus Lengkap Pskologi. Kartini-Kartono.Jakarta: PT. Grafindo Persada.

Cempaka. 1995. Berebut Konsumen of Akhir Tahun 350 NII/13-19 Desember.

Clemente, D.A. Jr., 1993. Odd Pricing in Se lected Retail Outlets. Journal of Marketing Research. vol. 10. p. 33-38.

Ellis, H.C. and Hunt, R.A. 1993. "Who is the Deal Prone Consume?" Consumer Research. Vol. 15. p. 57-62.

Engel, J.F. 1975. Porilaku Konsumen. Jilid 1. Alih bahasa: FX. Budiyanto. Jakarta: binarupa Aksara.

Furqony, R. 1996. "Atnbut Ekstrinskk Produk Sebagai Indikator Perceived Ouality". Skripsi. (Tidak diterbitkan) Yogyakarta: F. Psikologi UGM.

Hahn, H.B.R. 1976. An Introduction to Theories of Learning. New Jersey: PrentinceHall Inc. Engle Wood Cliffs.

Hansen, F. 1972. ConsumerChoiceBehav- ior, A Cognitive Theory New York: The Free Press. Macmillan Co.

Kertajaya, H. 1996. "Arti Sebuah Nama". SWA Sembada. 08/X\|/30 Mei-19 Juni.

Kotler, P. 1988. Marketing Management: Analysis, Planning. Implementation and Control, New Jersey: Prentice-Hall, Inc. and Roberto, E.L. 1989. Social Marketing. New York: the Free Press A Division of Macmillan Inc.

Lambert, Z. 1975. Perceived Price Related to Odd and Even Price Ending. Journal of Fetaling. Vol. 51. p. 13-32.

Loudon, D.L. Bitta, A.J.D. 1984. Consumer Behavior: Concept, and Aplication. Singapore: McGraw-Hill Book Company.

Milliman R.E. 1982. "Using Background Music to Aftect the Behavior of Supermarket Shoppers". Journal of Marketing. vol. 46. p. 86-91.

Monroe. 1992. Seri Pemasaran dan Promosi: Kebijakan Harga. Alih bahasa: Soesanto Boedidarmo. Jakara: PT. Elex Media Komputindo.

Moore, D. and Hutchinson, J.W., 1984. "Issues Surrounding the Examination of Delay Efect of Advertising", Advances in Consumer Research. Vol. 25. p. 650655 .

Mowen, J.C. 1990. Consumer Behavior. 2ndEd. Jakarta: Macmillan Publishing Co.

Rakhmat, J. 1993. Psikologi Komunikasi. Bandung: PT. Remaja Rosdakarya.

Vitriani, R.W. 1995. "Hubungan Antara Harga diri dengan Minat Membeli Pakaian Bermerk pada Remaja". Skripsi (tidak diterbitkan) Yogyakarta: F. Psikologi UGM. 